\title{
MASA REMAJA DAN PENGETAHUAN KESEHATAN REPRODUKSI SANTRI PUTRI PONDOK PESANTREN AL-HAMDANIYAH
}

\author{
Nurul Azizah ${ }^{1)}$, Rafhani Rosyidah' ${ }^{2)}$, Dra. Dwi Nastiti, M.Si ${ }^{3)}$ \\ ${ }^{1,2,3}$ Fakultas Ilmu Kesehatan, Universitas Muhammdiyah Sidoarjo \\ Email: : nurulazizah@umsida.ac.id ${ }^{1}$,rafhani.rosydah@umsida.ac.id ${ }^{2}$,nastitidwi19@yahoo.co.id ${ }^{3}$
}

\begin{abstract}
Abstrak
Berdasarkan hasil survey di Pondok putri pesantren Al-Hamdaniyah meunjukkan seluruh santri putri merupakan kategori remaja, namun dipondok pesantren para santri putri tidak pernah mendapatkan pendidikan tentang perkembangan remaja dan kesehatan reproduksi, sehingga para santri belum mengetahui bagaimana perubahan yang dialamai masa remaja baik secara fisik maupun psikologis, serta tidak dapat mengenali jika terdapat penyakit atau kelianan pada organ reproduksinya. Metode pelaksanaan kegiatan ini dengan ceramah yakni dengan mengadakan penyuluhan yang di laksaakan pada tanggal 10 maret 2020 dengan tema perkembangan remaja dan kesehatan reproduksi wanita, yang mengupas tentang perkembangan remaja dan berbagai masalah yang terjadi pada remaja, termasuk antisipasi dan bahaya penggunaan NAPZA, serta bahaya pergaulan bebas remaja. Kemudian dilanjutkan dengan pemberian edukasi penyuluhan tentang kesehtan reproduksi remaja wanita, mulai dari pengenalan organ reproduksi, perubahan yang terjadi pada organ reproduksi remaja wanita, serta pengenalan kelainan dan masalah kesehatan reproduksi remaja wanita. Hasil kegiatan program kemitraan masyarakat terhadap santri pondok pesantren Al-Hamdaniyah ini memberikan suatu pengetahuan lebih dan baru kepada para santri dengan harapan para remaja dapat tumbuh menjadi dewasa yang baik dan sehat. Saran, di pondok pesantren hendaknya kegiatan seperti ini dilakukan secara rutin setiap tahun untuk menambah pengetahuan dengan topik yang baru dan menarik
\end{abstract}

Kata Kunci: Kesehatan, Reproduksi, Remaja, Pondok, Pesantren

\begin{abstract}
According to the survey result in Al-Hamdaniyah boarding school shows that the entire female students is a teenagers, but they never received education about teenager growth and reproduction health, so they unable to identify whether there is exist any growth experienced by teenagers physically and psychologically, and unable to recognize whether they experience any disease or abnormalities in their reproduction organ. The method used to conduct this event is by lecture and counseling talk about teenager growth and female reproduction healthiness that are done at $10^{\text {th }}$ march 2020 to analyze about teenager growth and some common problems that are usually felt by teenagers, including anticipations and risks of forbidden drugs usage, also adolescent free promiscuity. Then followed by counseling education about female reproduction organ healthiness start from recognition of the organ, shifts that happens inside the organ, and the recognition of the abnormalities and disease of the female reproduction organ. This community partnership to AlHamdaniyah boarding school provides more and new knowledge for students with the hopes that the teenagers grow up well and healthy. As a suggestion, boarding school partner should have to carry out this event periodically every year to improve and enrich the student knowledge with new and interesting topic.
\end{abstract}

Keywords: Health, Reproduction, Teenager, Boarding School 


\section{PENDAHULUAN}

Pondok pesantren Al-Hamdaniyah, Desa Siwalan Panji Kecamatan Buduran Sidoarjo Jawa Timur merupakan salah satu pondok tertua di Indonesia. Jumlah santri putri pondok pesantren saat ini sekitar 130 orang dengan luas pondok skitar 2000 meter persegi.

Santri putri pondok pesantren AlHamdaniyah seluruhnya masuk kategori remaja namun tidak pernah mendapatkan pendidikan dan pengetahuan tentang perkembangan remaja serta kesehatan reproduksi pada remaja putri. Sehingga para santri tdak dapat mengenali jika terdapat masalah atau penyakit pada organ reproduksinya.

Masa remaja dapat disebut juga dengan pubertas yang dianggap sebagai salah satu masa pencarian jati diri atau krusial karena pada masa tersebut telah terjadi perubahan baik fisik, psikososial, serta kematangan organ seksual (Jaruratanasirikul, et al 2014).

Remaja yang sedang mengalami pubertas membutuhkan adanya bimbingan dari lingkungan sekitanya, orang tua, sekolah, agar para remaja dapat melalui pubertas pada masa remaja dengan baik. Oleh karena itu pengetahuan tentang kesehatan reproduksi harus diberikan pada remaja dengan harapan para remaja dapat melewati masa pubertas dengan baik dan terhindar dari masalah kesehatan reprodusi (Unicef, 2011).

Namun kenyataanya masih banyak yang kita temui informasi tentang perkrbangan remaja dan kesehatan reproduksi justru didapatkan setelah melewati remaja, bahkan tidak tau sama sekali hingga mencapai usia dewasa (Denno, 2020) hal ini dikarenakan sebgaian besar orang tua merasa tabu membicarakan topik kesehatan reproduksi bahakan dianggap tidak pantas untuk dibicarakan pada anak remaja.
Penyabab lain menyatakan karena mereka merasa khawatir bila diberikan pengetahuan reproduksi justru dapat merangsang rasa penasaran sehingga dapat menjerumuskan kepada perilaku seksual yang tidak benar(Senderowitz, 2000) Akibatnya, kebanyakan para remaja tertarik mencari informasi reproduksi dan seksual melalui media, teman, dan pornografi (Situmorang, 2003)

\section{METODE PELAKSANAAN}

Kegiatan ini dimulai dengan melakukan survei untuk melihat dan menganalisis situasi, kemudian melakukan pendekatan dan meminta persetujuan terhadap pimpinan untuk workshop dan penyuluhan tentang kesehatan reproduksi pada santri pondok pesantren putri AlHamdaniyah. Kegiatan dilakukan dengan metode ceramah melalui penyuluhan sebagai berikut :

\section{a. Penyuluhan kesehatan remaja}

Pelaksaan pada kegitan ini pertama kami mengadakan workshop dan penyuluhan tentang kesehatan remaja, dengan mengenali perkembangan remaja perempuan dari masa kanak-kanak menuju dewasa, tentang perubahan yang terjadi baik secara fisik maupun psikologis pada masa remaja, kemudian kami juga mengenalkan jenis obatobatan terlarang, dampak buruknya serta resiko yang terjadi pada penggunaan NAPZA. Selain itu kami informasikan kepada para remaja tentang bahaya dari pergaulan bebas dikalangan remaja dengan harapan hal tersebut dapat di hindari oleh para santri putri pondok pesantren Al-Hamdaniyah. 


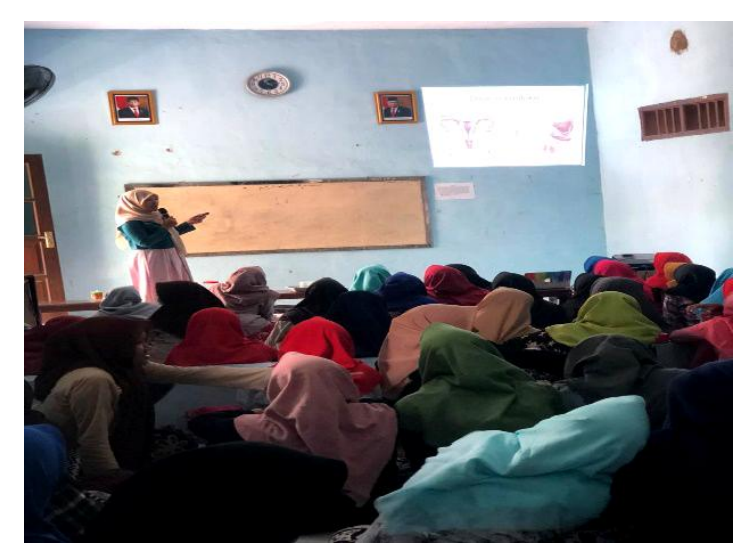

\section{b. Penyuluhan Kesehagtan reproduksi remaja}

Berikutnya kami mengadakan workshop dan penyuluhan kesehatan reproduksi remaja putri, dimulai dengan pengenalan organ repoduksi wanita, perubahan organ reproduksi yang terjadi pada remaja putri dari anak-anak menuju remaja, mentruasi dan gajala normal yang terjadi pada setap siklus menstruasi, serta gangguan dan penyakit yang dapat perjadi pada organ reproduksi

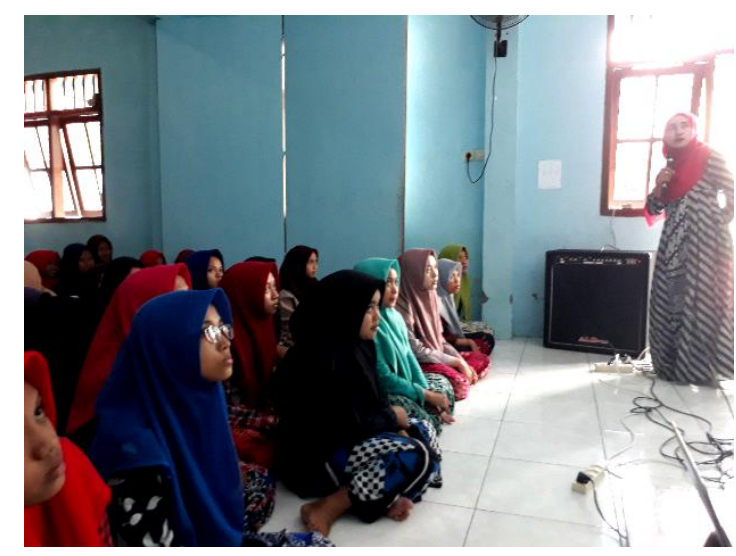

\section{HASIL DAN PEMBAHASAN}

a. Workshop penyuluhan tentang kesehatan remaja telah dilaksanakan pada tanggal 10 maret 2020 di aula pondok pesantren putri Al-Hamdaniyah, hasil yang di dapatkan para santri dapat memahami tentang kesehatan reproduksi dengan baik, para santri mendapatkan pengetahuan baru tentang kesehtan remaja, bahaya NAPZA (Narkotika, Psikotropika dan zat adiktif lainnya), serta pergaulan bebas, penyuluhan diikuti oleh santri dengan antusias di akhir penyuluhan terdapat beberapa santri yang mengajukan pertanyaan, serta menjawab saat presentator memberikan review dari materi yang telah disampaikan.

b. Workshop dan penyuluhan tentang kesehatan reproduksi remaja telah dilaksanakan pada tanggal 10 maret 2020 di aula pondok pesantren putri AlHamdaniyah, hasil menunjukkan para santri dapat memahami pengetahuan tentang kesehatan reproduksi remaja wanita dengan baik, serta seputar masalah yang terjadi pada organ reproduksi wanita terutama pada masa menstruasi. Para santri mengikuti acara dengan antusias hingga selesai, serta terdapat beberapa santri yang mengajukan pertanyaan terkait masalah yang mereka alami, serta menjawab pertanyaan saat presentator memberikan review dari materi yang telah disampaikan.

\section{KESIMPULAN}

Kegiatan Program pengabdian masyarakat ini telah dilaksanakan, para santri putri pondok pesantren Al-Hamdaniyah. Telah mendapatkan pengetahuan baru tentang perkembangan remaja dan kesehatan reproduksi remaja wanita.

\section{REFERENSI}

Jaruratanasirikul S, Yuenyongwiwat S, Kreetapirom P, Sriplung H. Age of onset of pubertal maturation of Thai boys. J Pediatr Endocrinol Metab. 2014;27(3-4):215-20.

Unicef. The State of the World's Children 2011: Adolescence-an Age of Opportunity. Unicef. 2011. 137 p.

Denno DM, H MP, Hoopes AJ, D M. Effective Strategies to Provide Adolescent Sexual and Reproductive Health Services and to Increase Demand and Community Support Effective Strategies to Provide Adolescent Sexual and Reproductive Health Services and to 
PENAMAS ADI BUANA

Volume 04, Nomor 1, 01 Juli 2020

Increase Demand and Community Support. J Adolesc Heal [Internet]. 2015;56(1):S22-41. Diperoleh dari: http://dx.doi.org/10.1016/j.jadohealth. 2014.09.012. Diakses 25 Mei 2020

Senderowitz J. A review of program approaches to adolescent reproductive health. USAID Contract
P ISSN 2622-5727

E ISSN 2622-5395

No. CCP-C-00-93- 00011-12. 2000. viii, 63.

Situmorang A. Adolescent Reproductive Health in Indonesia. STARH Program. 2003.

Gomes, Faustino C. 2003. Manajemen Sumber Daya Manusia.Yogyakarta : Andi Offset 